\title{
Determination of water quality variables, endotoxin concentration, and Enterobacteriaceae concentration and identification in southern High Plains dairy lagoons ${ }^{1}$
}

\author{
C. W. Purdy, ${ }^{*}$ R. N. Clark, ${ }^{*}$ and D. C. Straus ${ }^{1}$ \\ *USDA, Agricultural Research Service, Conservation and Production Research Laboratory, PO Drawer 10, Bushland, TX 79012 \\ †Department of Microbiology and Immunology, Texas Tech University Health Sciences Center, Lubbock 79430
}

\begin{abstract}
The objectives of this study were to determine the concentration of endotoxin, determine 20 water quality variables, and identify and enumerate fungal and bacterial pathogens from United States southern High Plains dairy lagoons and control lakes during summer and winter. Water samples were collected in triplicate from the north, south, east, and west quadrants of each body of water. The mean ( \pm SEM) winter dairy lagoon endotoxin concentration was significantly higher $(9,678$ $\pm 1,834 \mathrm{ng} / \mathrm{mL})$ than the summer concentration $(3,220$ $\pm 810 \mathrm{ng} / \mathrm{mL}$ ). The mean endotoxin concentration of the 2 control lakes (summer: $58.1 \pm 8.8 \mathrm{ng} / \mathrm{mL}$; winter: $38.6 \pm 4.2 \mathrm{ng} / \mathrm{mL}$ ) was significantly less than that of the dairy lagoons. Two hundred-one Salmonella enterica spp. isolates were identified, 7 serovars were recovered from the dairy lagoons, and 259 Salmonella ssp. were identified from 5 other dairy locations (milk barn, ditch effluent, settling basin, feed alley pad flush, and center pivots). Twenty-eight Salmonella spp. were identified from center pivot water. Escherichia coli O157:H7 pathogens were isolated from other dairy locations but not from lagoons. Neither Salmonella spp. nor E. coli O157:H7 were identified from control lakes. Enterobacteriaceae opportunistic pathogens were isolated from both dairies and control lakes. Important mesophilic and thermophilic catabolic (to manure biosolids) fungal isolates were identified from dairy effluent locations, but no thermophilic fungal isolates were cultured from the control lakes. Adequate curing of green forage following center pivot irrigation is important to kill lagoon water enteric pathogens, even though the lagoon water is mixed with fresh water. Recirculating lagoon water to flush the feed alley pad, where cows stand while

Received June 18, 2009.

Accepted December 29, 2009.

${ }^{1}$ Mention of trade names or commercial products in this article is solely for the purpose of providing specific information and does not imply recommendation or endorsement by the US Department of Agriculture.

${ }^{2}$ Corresponding author: David.Straus@ttuhsc.edu
\end{abstract}

eating, to remove manure and using lagoon water to abate dairy dust in loafing pens and unimproved dairy roads is inconsistent with good environmental practice management.

Key words: wastewater bacteria and fungi, dairy lagoon, endotoxin, Salmonella spp

\section{INTRODUCTION}

Increased regulation (both federal and state in the past $10 \mathrm{yr}$ ) has occurred because of the potential of concentrated animal feeding operations (CAFO) to contaminate the environment with feces and urine. Therefore, air, soil, and water pollution by CAFO have become important public issues. However, few published reports concern various aspects of fecal contamination from CAFO such as hormones, endotoxins, bacterial and fungal toxins, and infectious pathogens, to mention a few (Cole et al., 2000). This is especially true of fungal organisms in dairy lagoons on the United States southern High Plains (SHP), which includes Texas, New Mexico, and Oklahoma. It is our intention that facts concerning the concentrations of these pollutants be established in order to better understand the problems and how to solve them. Some questions should be asked. How long do these pollutants stay in the lagoon environment? How quickly are they degraded, and what microbes efficiently degrade these pollutants into harmless substances? What management practices best help speed up the process of biodegradation? What management practices help distribute these pollutants to a larger environmental area? What practices increase the chance of human and animal exposure to these pollutants? And finally, what problems do these contaminants present and how can dairy managers avoid exacerbating them? All of these questions need to be answered; however, we first need to know what types of pollutants exist in CAFO lagoons and their concentrations.

Large dairies with 2,500 to 7,000 head of milking cows are becoming commonplace on the SHP. This is similar to the feeder calf feedyard industry that moved from the Midwest to the SHP 50 yr ago (Uvacek, 1984). 
The present influx of dairies came for the same reasons as the feeder calf industry: greater undeveloped land area for buildings, animals and manure management, and a drier climate. Air and water pollution appeared to be less of a problem because fewer towns or large cities were present and there was less danger of polluting streams and rivers. Also, the presence of shallow lakes (playas) that were ephemeral and from which there was no drainage appeared to have advantages for runoff retention (Purdy et al., 2001b). The Ogallala Aquifer, which lies beneath the High Plains of the United States and runs from western Texas to South Dakota, is very deep (more than 500 feet) and ground water contamination appeared to be less of a problem. The Dockum, a minor aquifer underlying the Ogallala aquifer, extends into parts of western Texas and New Mexico. For reasons such as dust production and possible aquifer contamination, the CAFO are not as welcome as they once were. It is becoming increasingly difficult for dairies to find municipalities that offer favorable economic incentives and welcome them openly (Burchfield and Linderoth, 1999).

The tendency for CAFO is to become larger in order to become more profitable and to garner greater economic advantages. The larger CAFO become, the greater potential there is for environmental problems to develop (Centner, 2001). Pollution of air and water are of primary importance (Thorne, 2007). An important question for which answers are needed is: what types of pollutants exist in CAFO lagoons and in what concentrations are they found compared with control lakes?

Our hypothesis is that dairy lagoon water has sufficient pollutants and pathogens to warrant careful use to prevent the zoonotic spread of pathogens and to prevent pollution of humans and animals. The objectives of this study were to determine the concentration of endotoxin and pathogens and to identify and enumerate viable fungi from 4 SHP dairy lagoons and 2 control lakes during the summer and winter, as well as to determine 20 chemical and physical variables during the summer. A survey of potentially pathogenic fungi and bacteria as well as endotoxin in wastewater from dairies is required to better understand the potential for enhanced exposure to toxins and zoonotic pathogens where dairies use wastewater from lagoons for dust reduction and crop enhancement.

\section{MATERIALS AND METHODS}

\section{Dairy Lagoons}

Four dairy lagoons were designated as DL 3, DL 4, DL 5, and DL 6. Milk cow numbers per dairy ranged from 2,500 to 7,000 head. Dairy farms themselves were referred to as dairy 3 , dairy 4 , dairy 5 , and dairy 6 . The 4 dairies were located in the northeastern part of New Mexico. The mean $( \pm$ SEM) surface area of the 4 dairy lagoons was $18,864 \pm 3,708 \mathrm{~m}^{2}$.

\section{Control Lakes}

Two control lakes were designated as CL 1 and CL 2. Water samples (8 samples/location, 4 in summer and 4 in winter) from the 2 control lakes compared against samples from the 4 dairy lagoons. The control lakes were $1.1 \mathrm{~km}$ apart and were $6.2 \mathrm{~km}$ from the nearest dairy studied (dairy 5). The surface area of CL 1 was $26,000 \mathrm{~m}^{2}$ and the surface area of CL 2 was $15,300 \mathrm{~m}^{2}$. Both control lakes contained fish, were inhabited by ducks and geese, and supported migratory water fowl.

\section{Sample Collection for Endotoxin Analysis}

Water samples for endotoxin analysis were collected (8 samples/location, 4 in summer and 4 in winter) in sterile 30-mL glass vials (Wheaton Scientific Co., Millville, NJ) previously heat-treated at $180^{\circ} \mathrm{C}$ for $3 \mathrm{~h}$ to ensure destruction of residual endotoxin. The vials were fitted with new vinyl fluted stoppers and aluminum seals (Wheaton Scientific Co.). Water samples were collected at sites $1 \mathrm{~m}$ from the shoreline at the air-water interface in each of 4 quadrants (north, south, east, and west) in each of the 4 lagoons and 2 control lakes, with no disruption of the bottom sediment (Purdy et al., 2001b).

\section{Kinetic Limulus Lysate Assay}

Endotoxin was measured by use of the kinetic chromogenic quantitative Limulus amebocyte lysate assay (Williams and Halsey, 1997), which is nonreactive to glucans (Bio Whittaker Inc., Walkersville, MD). Aliquots of the extracts were serially diluted in 10-fold increments with pyrogen-free water. A $100-\mu \mathrm{L}$ aliquot of each dilution was mixed with $100 \mu \mathrm{L}$ of freshly prepared Limulus amebocyte lysate containing chromogenic substrate in a pyrogen-free microtiter plate (Dynatech Corp., Chantilly, VA) that was kept at $37^{\circ} \mathrm{C}$. Color development was monitored every $15 \mathrm{~s}$ with a microtiter plate-reading spectrophotometer (MR5000, Dynatech Corp.). The time interval required to reach 0.03 absorbency was determined and this interval was compared with a standard curve covering the range of $5 \mathrm{ng} / \mathrm{mL}$ to $0.5 \mathrm{pg} / \mathrm{mL}$. Standards were linear over a 5 -log range on a log-log plot and were used for data analysis. Unknown samples were calculated by linear interpolation. All dilutions were assayed in duplicate and a parallel dilution was spiked with $50 \mathrm{pg}$ of en- 
dotoxin to assess any enhancement or inhibition of activity caused by the method. Only those dilutions that did not have enhancement or inhibition and were parallel to the standard curve were used. Mean values were determined after 3 replications of the sample. Mean coefficient of variation for these assays was $7.6 \%$. To convert endotoxin activity to equivalent mass units of the reference standards (EC6, US Pharmacopeia), a factor of 10 equivalents (U/ng) was used.

\section{Sample Collection for Water Quality Analysis}

Water quality samples were collected in the summer from the north, south, east, and west quadrants of each of the 4 dairy lagoons and 2 control lakes, $1 \mathrm{~m}$ from the shoreline by use of recommended procedures (Environmental Protection Agency, 1997). Water quality samples were placed in plastic or glass sampling bottles supplied by the analytical laboratory with specific details on filling for each assay. The water samples were placed on ice in a portable cooler and delivered to the laboratory within $4 \mathrm{~h}$ of collection time in order for the results to be certified. All chemical tests were performed and analyzed by standard methods (Cook, 1989) by ASK Laboratories Inc. (Amarillo, TX), which is accredited by the National Environmental Laboratory Accreditation Conference.

Dairy lagoon 3, DL 4, DL 5, and DL 6 and control lakes CL 1 and CL 2 were examined for water quality during the summer by determining values for biological oxygen demand (5-d method), chemical oxygen demand, $\mathrm{NO}_{3}-\mathrm{N}, \mathrm{NH}_{4}-\mathrm{N}$, total Kjeldahl $\mathrm{N}(\mathbf{T K N})$, total organic $\mathrm{C}$, total $\mathrm{P}$, orthophosphate, $\mathrm{B}, \mathrm{Cl}^{-}, \mathrm{Na}^{-}, \mathrm{Ca}^{2+}, \mathrm{Mg}^{2+}$, $\mathrm{K}^{+}, \mathrm{SO}_{4}{ }^{2+}, \mathrm{Zn}^{2+}$, total alkalinity, electrical conductivity, turbidity, and $\mathrm{pH}$.

\section{Sample Collection for Microbial Analysis}

Samples for microbial analysis were collected in 2-L high density polyethylene bottles (Qorpak, Fisher Scientific, Waltham, MA) using a high density polyethylene dipper and plastic zipper-lock bags that were used as skimmers, in triplicate. Sample locations included 1 $\mathrm{m}$ from the shoreline, at the flowing water-air interface, 4 sites around the lagoons or control lakes, at the milk barn origin, sprinklers used to wash udders before milking, effluent exiting milk barn, upper ditch, lower ditch, settling basin, upper alley flush, lower alley flush, and at center pivot irrigation. All water samples were placed on ice in a portable cooler and immediately transported to the microbiology laboratory for processing.

\section{Culture of Gram-Negative Bacteria}

Each surface water sample collected for microbial analysis was assayed by 10 -fold dilutions $\left(10^{-1}\right.$ through $\left.10^{-6}\right)$. The serial dilutions were prepared from 3 samples from each side of the bodies of water by inoculating $10 \mathrm{~mL}$ of water into glass bottles containing $90 \mathrm{~mL}$ of sterile physiological saline $(0.15 \mathrm{M} \mathrm{NaCl})$ solution. One-tenth of a milliliter of each serial dilution was inoculated onto the surface of MacConkey agar (MAC; Becton, Dickinson and Co., Franklin Lakes, NJ) containing novobiocin $(0.025 \mathrm{~g} / \mathrm{L}$; Sigma Chemical Co., St. Louis, MO) and cycloheximide (100 mg/L; Sigma Chemical Co.). The inoculated Petri plates (Becton, Dickinson and Co.) were spread with sterile bent-glass rods and then incubated (Forma Scientific, Marietta, $\mathrm{OH})$ at $37^{\circ} \mathrm{C}$ for $24 \mathrm{~h}$. The colonies were counted and reported as colony forming units per milliliter. Different type colonies (pink lactose fermentors or colorless nonlactose fermentors; Difco, 1984) were Gram stained and subcultured 3 times on MacConkey agar, and then the last subculture was mixed with sterile reconstituted, double strength, dried milk (Albertson, Amarillo, TX) in 2-mL plastic vials (Falcon screwcap plastic culture tube, Becton, Dickinson and Co.) and stored frozen (Ultrafreezer, Forma Scientific) at $-85^{\circ} \mathrm{C}$.

\section{Culture of Escherichia coli}

Fifty milliliters of wastewater or lake water was mixed with $50 \mathrm{~mL}$ of a double-strength $E$. coli modified enrichment broth (Becton, Dickinson and Co.; Hepburn et al., 2002) with novobiocin $(0.025 \mathrm{~g} / \mathrm{L})$ in a $250-\mathrm{mL}$ Erlenmeyer flask, and the flask was placed in a rotary shaker incubator (C25, New Brunswick Scientific, Edison, NJ) at $37^{\circ} \mathrm{C}$ for $24 \mathrm{~h}$. The process was repeated a second time for replication. The bacterial solution from the flask was streaked onto a MacConkey-D-sorbitol agar plate (Becton, Dickinson and Co.) and incubated at $37^{\circ} \mathrm{C}$ for $24 \mathrm{~h}$. The colorless colonies do not ferment sorbitol and were reported as presumptive of $E$. coli O157:H7, whereas pink colonies (sorbitol fermentors) were recorded as presumptive of E. coli. Both pink and colorless colonies were isolated and identified by an automated Biolog system (Biolog Inc., Hayward, CA) as described previously (Purdy et al., 2004b).

\section{Culture of Salmonella spp.}

Bacteriologic culture of Salmonella spp. isolations were performed by diluting $10 \mathrm{~mL}$ of wastewater or control lake water into $10 \mathrm{~mL}$ of a double-strength Salmonella selenite brilliant-green with sulfapyridine (0.5 g/L) enrichment broth (SBG Sulfa, Becton, Dickinson and Co.) in a glass Erlenmeyer flask. The flask was placed in a shaker incubator at $37^{\circ} \mathrm{C}$ for $24 \mathrm{~h}$. The process was repeated a second time for replication (Purdy et al., 2004a). The broth solution was then streaked 
onto brilliant-green plates (Becton, Dickinson and Co.), xylose lysine deoxycholate (XLD) plates (Becton, Dickinson and Co.), and MAC plates and incubated for $24 \mathrm{~h}$ at $37^{\circ} \mathrm{C}$. The plates were then examined for Salmonellalike colonies. The colonies were then stab-inoculated into tubes containing urease (Becton, Dickinson and Co.), triple sugar iron agar (Becton, Dickinson and Co.), lysine iron agar (Becton, Dickinson and Co.), and XLD agar. Salmonella-like colonies were also streaked onto tryptose agar plates (Becton, Dickinson and Co.) with $5 \%$ bovine blood and incubated at $37^{\circ} \mathrm{C}$ for 24 h. Salmonella-like colonies that exhibited the correct biochemical profile and no hemolysis were recorded as presumptive Salmonella spp. isolates. A duplicate of each culture was stored at $-85^{\circ} \mathrm{C}$. The Salmonella cultures were shipped to the National Veterinary Services Laboratory (Ames, IA) for verification as Salmonella enterica and serotyping.

\section{Culture of Fungi and Yeast}

Waterborne mesophilic fungi and yeast were cultured on Littman oxgall agar (LOA; Becton, Dickinson and Co.) and incubated (custom-fabricated walk-in incubator, USDA-ARS, Bushland, TX) at $28^{\circ} \mathrm{C}$ for $10 \mathrm{~d}$, whereas thermophilic fungi were grown on malt extract agar (Becton, Dickinson and Co.) at $50^{\circ} \mathrm{C}$ for 4 to $10 \mathrm{~d}$. The LOA medium contained an inhibitor (crystal violet, $0.01 \mathrm{~g} / \mathrm{L}$; Sigma Chemical Co.) to prevent overgrowth of mesophilic fungi and an antibiotic (streptomycin sulfate, $100 \mathrm{mg} / \mathrm{L}$; Sigma Chemical Co.) to inhibit bacterial growth. Antibacterial inhibitors (chlortetracycline, $5 \mathrm{mg} / \mathrm{L}$; streptomycin sulfate, $100 \mathrm{mg} / \mathrm{L}$; Sigma Chemical Co.) were incorporated into malt extract agar to inhibit bacterial growth. Fungal and yeast activity of the water were determined by using standard 10-fold microbial dilution techniques, and mean concentrations were reported as colony forming units per milliliter. Random selected yeast colonies were identified to the genus and species level by using the automated Biolog system.

Mesophilic fungal colonies were identified (Larone, 1995) to the genus level and thermophilic fungi were identified by genus and species on the basis of colony gross morphology, color (surface and reverse), and microscopic examination (320× magnification) of hyphae morphology (aseptate or septate), microconidia, macroconidia, and other fruiting structures. Microscopic identification of the fungal colony was made using a $3-\mathrm{cm}$ piece of clear cellophane tape, which was bent into a loop with the sticky side on the exterior. The tape was lightly touched to the surface of a fungal colony and the exposed tape was then placed into a drop of lactophenol cotton blue stain (Hardy Diagnostics,
Santa Maria, CA) on a microscope slide and observed with $320 \times$ magnification.

\section{Statistical Analyses}

Data were analyzed by ANOVA using the general linear models procedure. With this procedure, the dependent variable was endotoxin concentration and the independent variables were sources of water, season, sites sampled, and all their interactions. The coefficient of determination value was used to determine the best overall models. Significant differences between sources of water samples were further evaluated by use of the Bonferroni and Dunnett adjusted paired $t$-test. Differences were considered significant at $P<0.05$. Titer data were transformed (normalized) by multiplying the titer against natural $\log +1$ for statistical analysis.

\section{RESULTS}

\section{Endotoxin Concentrations of Lagoon Wastewater}

The overall linear model $\left(\mathrm{R}^{2}=0.96 ; P<0.0001\right)$ for mean $( \pm \mathrm{SEM})$ endotoxin concentrations for DL 3 $(3,771 \pm 512 \mathrm{ng} / \mathrm{mL})$ and DL $5(2,652 \pm 324 \mathrm{ng} / \mathrm{mL})$ was significantly $(P<0.05)$ less than for DL $4(10,153$ $\pm 3,951 \mathrm{ng} / \mathrm{mL})$ and DL $6(9,220 \pm 1,039 \mathrm{ng} / \mathrm{mL})$. The mean $( \pm$ SEM) endotoxin concentrations of the 4 dairies were significantly $(P<0.05)$ higher in the winter $(9,678.8 \pm 1,834 \mathrm{ng} / \mathrm{mL})$ compared with summer $(3,220$ $\pm 811 \mathrm{ng} / \mathrm{mL}$ ). The dairy lagoon endotoxin concentrations were compared among dairies and control lakes for summer and winter (Table 1). The mean endotoxin concentration of the dairy lagoons was 248 -fold greater in winter and 55-fold greater in summer than that measured in the control lakes in the same seasons.

\section{Water Quality}

The mean concentrations of 20 variables for 4 dairy lagoons and 2 control lakes sampled in the summer are reported in Table 2. Eighteen of the variables were significantly different among the dairy lagoons. Only 2 variables, $\mathrm{NO}_{3}-\mathrm{N}$ (range: $0.49-0.50 \mathrm{mg} / \mathrm{L}$ ) and orthophosphate (range: $44.1-88.2 \mathrm{mg} / \mathrm{L}$ ) were not significantly different among the dairies. The concentration of $\mathrm{SO}_{4}{ }^{2+}$ was higher in DL 5 compared with the other 3 dairy lagoons. At DL 3, the concentration of $\mathrm{K}^{+}$was $891 \pm 13.5 \mathrm{mg} / \mathrm{mL}$, which was 5.5 times greater than at DL 5 , where the concentration of $\mathrm{K}^{+}$was $161 \pm 7.0$ $\mathrm{mg} / \mathrm{L}$. In addition, there was a significantly (2.6 times) higher concentration $(125.3 \pm 7.2 \mathrm{mg} / \mathrm{L})$ of total $\mathrm{P}$ in DL 3 compared with DL $4(47.6 \pm 3.5 \mathrm{mg} / \mathrm{L})$. There was a significantly (5.5 times) higher biological oxygen 
Table 1. Mean endotoxin concentration $(\mathrm{ng} / \mathrm{mL})$ at 4 dairy lagoons and 2 control lakes in summer and winter seasons ${ }^{1}$

\begin{tabular}{|c|c|c|c|c|c|c|c|c|c|}
\hline Water source & No. of samples & \multicolumn{4}{|c|}{ Summer } & \multicolumn{4}{|c|}{ Winter } \\
\hline Dairy lagoon & 16 & $3,220^{\mathrm{a}}$ & 811 & 11,300 & 107 & $9,679^{\mathrm{a}}$ & 1,834 & 27,200 & 2,100 \\
\hline
\end{tabular}

${ }^{\mathrm{a}, \mathrm{b}}$ Values within columns with different superscripts differ $(P<0.05)$ by the Bonferroni paired $t$-test.

${ }^{1}$ All bodies of water were located on the southern High Plains.

demand in DL $4(3,222.5 \pm 196.2 \mathrm{mg} / \mathrm{L})$ compared with in DL $6(581 \pm 42.1 \mathrm{mg} / \mathrm{L})$, and a significantly (11.8 times) higher chemical oxygen demand in DL $3(7,950$ $\pm 1,240.4 \mathrm{mg} / \mathrm{L})$ compared with in DL $4(673.3 \pm 94.3$ $\mathrm{mg} / \mathrm{L}$ ). The mean values of the variables for the 2 control lakes were significantly less compared with the dairy lagoons. The $\mathrm{NO}_{3}-\mathrm{N}$ values were below the detectable level in both the dairy lagoons and control lakes.

\section{Concentration of Gram-Negative Bacteria}

The overall mean $( \pm \mathrm{SEM})$ concentration of gramnegative bacteria from dairy wastewater grown on MacConkey agar $(1.69 \mathrm{E}+05 \pm 3.43 \mathrm{E}+04 \mathrm{cfu} / \mathrm{mL})$ was significantly higher than that from control lakes $(1.05 \mathrm{E}+02 \pm 1.68 \mathrm{E}+04 \mathrm{cfu} / \mathrm{mL})$. The mean winter concentration $(1.91 \mathrm{E}+05 \pm 5.51 \mathrm{E}+04 \mathrm{cfu} / \mathrm{mL})$ was significantly higher compared with the summer concentration $(9.79 \mathrm{E}+04 \pm 2.09 \mathrm{E}+04 \mathrm{cfu} / \mathrm{mL})$. There was a significance difference in mean concentration among dairies $4(4.10 \mathrm{E}+05 \pm 1.23 \mathrm{E}+05 \mathrm{cfu} / \mathrm{mL}), 3(8.27 \mathrm{E}+04$ $\pm 1.38 \mathrm{E}+04 \mathrm{cfu} / \mathrm{mL})$, and $5(1.25 \mathrm{E}+05 \pm 4.62 \mathrm{E}+04$ $\mathrm{cfu} / \mathrm{mL}$ ) by the Bonferroni's paired $t$-test, and all 4 dairies were significantly different by Dunnett's paired $t$-test. The overall specific wastewater dairy site mean concentrations at specific locations were the lowest at milking barn flush and udder sprinklers $(1.70 \mathrm{E}+02$ to $1.8 \mathrm{E}+02 \mathrm{cfu} / \mathrm{mL}$ ), followed by 4 locations at lagoons $(3.18 \mathrm{E}+04$ to $6.86+04 \mathrm{cfu} / \mathrm{mL})$. These are in increasing order: milk barn exiting effluent $(1.03 \mathrm{E}+05 \mathrm{cfu} / \mathrm{mL})$, end of feeding alley flush $(1.56 \mathrm{E}+05 \mathrm{cfu} / \mathrm{mL})$, beginning of feeding alley flush $(2.04 \mathrm{E}+05 \mathrm{cfu} / \mathrm{mL})$, end of wastewater ditch $(4.78 \mathrm{E}+05 \mathrm{cfu} / \mathrm{mL})$, and beginning of wastewater ditch $(6.46 \mathrm{E}+05 \mathrm{cfu} / \mathrm{mL})$. The mean concentration at the center pivot irrigation was $9.31 \mathrm{E}+03$ $\mathrm{cfu} / \mathrm{mL}$. There were significant $(P<0.001)$ interactions between site $\times$ season, site $\times$ location, season $\times$ location, and site $\times$ season $\times$ location.

Table 2. Water quality variables (mean \pm SEM) and maximum values from 4 dairy lagoons and 2 control lakes sampled on the southern High Plains during the summer ${ }^{1}$

\begin{tabular}{|c|c|c|c|c|}
\hline Variable $^{2}$ (mg/L unless noted) & \multicolumn{2}{|c|}{ Dairy lagoons } & \multicolumn{2}{|c|}{ Control lakes } \\
\hline COD & $3,342 \pm 777$ & 11,400 & $79.43 \pm 7.2$ & 121.0 \\
\hline Total alkalinity & $1,942 \pm 217$ & 3,310 & $70.88 \pm 1.9$ & 78.0 \\
\hline $\mathrm{EC}(\mathrm{mS} / \mathrm{cm})$ & $4.6 \pm 0.2$ & 12.40 & $0.193 \pm 0.002$ & 0.21 \\
\hline TOC & $783 \pm 84$ & 1,230 & $8.92 \pm 0.1$ & 9.4 \\
\hline TKN & $249 \pm 28$ & 407 & $1.03 \pm 0.1$ & 1.3 \\
\hline B & $0.8 \pm 0.05$ & 1.07 & $0.04 \pm 0.0$ & 0.05 \\
\hline $\mathrm{Ca}$ & $262 \pm 30$ & 528 & $22.95 \pm 0.6$ & 24.8 \\
\hline $\mathrm{Cl}$ & $318 \pm 22$ & 145 & $6.24 \pm 0.8$ & 8.3 \\
\hline $\mathrm{Mg}$ & $151 \pm 11$ & 225 & $2.15 \pm 0.3$ & 2.9 \\
\hline $\mathrm{K}$ & $590 \pm 79$ & 924 & $4.17 \pm 0.1$ & 4.4 \\
\hline $\mathrm{Na}$ & $197 \pm 16$ & 306 & $5.24 \pm 0.7$ & 7.2 \\
\hline Turbidity (\% at $650 \mathrm{~nm}$ ) & $3.55 \pm 0.46$ & 108.4 & $98.17 \pm 0.12$ & 99.20 \\
\hline
\end{tabular}

${ }^{1}$ Data were supplied by ASK Laboratories, Amarillo, TX. Control lakes mean values were significantly less than dairy lagoons.

${ }^{2} \mathrm{BOD}=$ biological oxygen demand; $\mathrm{COD}=$ chemical oxygen demand; $\mathrm{EC}=$ electrical conductivity; $\mathrm{TOC}=$ total organic $\mathrm{C}$; $\mathrm{TKN}=$ total Kjeldahl N. 
The overall mean $( \pm$ SEM) concentration of gramnegative lactose-fermenting bacteria was significantly greater for the dairies $(3.01 \mathrm{E}+05 \pm 2.57 \mathrm{E}+05 \mathrm{cfu} / \mathrm{mL})$ compared with the control lakes $(3.01 \mathrm{E}+01 \pm 6.66 \mathrm{E}+00$ $\mathrm{cfu} / \mathrm{mL}$ ). The mean concentration was increased in the winter $(1.43 \mathrm{E}+05 \pm 4.02 \mathrm{E}+04 \mathrm{cfu} / \mathrm{mL})$ compared with the summer $(8.40 \mathrm{E}+04 \pm 1.86 \mathrm{E}+04 \mathrm{cfu} / \mathrm{mL})$. Among the dairies, there were significant differences for dairies $3(7.33 \mathrm{E}+04 \mathrm{cfu} / \mathrm{mL}), 4(3.21 \mathrm{E}+05 \mathrm{cfu} / \mathrm{mL})$, and $5(1.07 \mathrm{E}+05 \mathrm{cfu} / \mathrm{mL})$. The overall mean concentration of nonfermenting gram-negative bacteria for the dairies was significantly higher $(3.59 \mathrm{E}+04 \mathrm{cfu} / \mathrm{mL})$ compared with control lakes $(7.49 \mathrm{E}+01 \mathrm{cfu} / \mathrm{mL})$, and the mean was significantly higher in the winter $(4.75 \mathrm{E}+04 \mathrm{cfu} /$ $\mathrm{mL})$ compared with the summer $(1.39 \mathrm{E}+04 \mathrm{cfu} / \mathrm{mL})$. Only dairy 3 contained significantly less non-lactose fermenting bacteria $(9.38 \mathrm{E}+03 \mathrm{cfu} / \mathrm{mL})$ compared with dairies 4,5 , and 6 (range: $1.77 \mathrm{E}+04$ to $8.88 \mathrm{E}+04 \mathrm{cfu} /$ $\mathrm{mL}$ ).

There were significant $(P<0.003)$ interactions between dairy lagoon and season and between dairy lagoon and lagoon sample location. The concentration ( \pm SEM) of gram-negative non-lactose fermenting bacteria (colorless) was $1.47 \mathrm{E}+04( \pm 2.79 \mathrm{E}+03) \mathrm{cfu} / \mathrm{mL}$, and there were significantly $(P<0.04)$ more in the winter $(1.9 \mathrm{E}+04 \mathrm{cfu} / \mathrm{mL})$ compared with in the summer $(1.03 \mathrm{E}+04 \mathrm{cfu} / \mathrm{mL})$. There was a significant $(P<$ $0.0001)$ interaction between dairy lagoon identity and season only.

\section{Identified Enteric Bacterial Isolates}

Fifty-eight gram-negative bacterial isolates from DL 4 and DL 6 in summer and winter were discovered (Table 3 ), and 71 gram-negative isolates were recovered during the same timeframe from CL 1 and CL 2. All samples were cultured on MacConkey-sorbitol agar and resulting colonies were identified by the automated Biolog system. Eight genera and 15 species were identified from the lagoons, and 7 genera and 17 species were identified from the control lakes. Twelve colonies were identified; parentheses indicate the number of isolates identified: Raoultella planticola/ornithinolytica (6), Escherichia coli (3), and Pseudomonas putida biotype A (3). Genera and species isolated from the control lakes in the summer were Citrobacter amalonaticus (1), Citrobacter braakii (2), Citrobacter freundii (5), Citrobacter sedlakii (1), Enterobacter amnigenus (2), Enterobacter asburiae (1), Enterobacter cloacae (16), Enterobacter hormaechei (2), Enterobacter nimipressuralis (11), Klebsiella oxytoca (1), Kluyvera ascorbata (2), Raoultella planticola/ ornithinolytica (1), and Raoultella terrigena (13).

Seventy-one gram-negative isolates were identified by the Biolog system from the wastewater flow on dairy 4 (milk barn effluent, ditch effluent, settling basin, and feeding alley flush) and dairy 6 (milk barn effluent, ditch effluent, udder sprinklers, feed alley flush, and center pivot): Burkholderia glumae (1), C. braakii (4), C. freundii, Citrobacter koseri (1), C. sedlakii (1), E. coli (32), E. coli O157:H7 (4), Flavimonas oryzihabitans (1), Morganella morganii (6), Proteus mirabilis (5), Proteus penneri/vulgaris (3), Providencia rettgeri (4), Pseudomonas aeruginosa (1), Pseudomonas fuscovaginae (1), P. putida biotype A (2), Pseudomonas resinovorans (1), Raoultella terrigena (2), and Salmonella choleraesuis (1).

\section{Salmonella spp.}

There were 201 isolates identified as Salmonella enterica spp. (out of 288 attempts) from the 4 dairy lagoons in summer and winter. The total rate of success using each of 3 media for Salmonella identification was as follows: MAC: 60/96 (63\%); brilliant green agar (BGA): 59/96 (61\%); and XLD: 82/96 (85\%). One hundred-fifteen Salmonella isolates were recovered from the 4 dairies in the summer and 88 were recovered in the winter. Of those Salmonella isolates, 1 was nontypeable and 1 was nonmotile. The most numerous lagoon Salmonella serovars were placed in descending order (Table 4). In addition to the dairy lagoon Salmonella spp. isolates, we analyzed and identified another 259 Salmonella enterica spp. in the wastewater flow from all locations sampled at the 4 dairies. Thirty-eight Salmonella spp. were identified in the milk barn effluent, 62 in the ditch effluent, 36 in the settling basin, 78 in the feed alley pad effluent, 17 from the sprinklers, and 28 from irrigation center pivots. The Salmonella spp. serovars identified were not different than those reported for the lagoons.

A total of 2,439 mesophilic filamentous fungal colonies were identified, whereas 6 colonies were unidentified; 13 colonies had no spores for identification and were recorded as M. sterile. Mesophilic fungal isolations seldom occurred at dilutions in excess of $1 \times 10^{-3} / 0.1$ $\mathrm{mL}$. Eighteen genera were identified from the 4 dairy lagoons, and the total number of fungal colonies for summer and winter were combined (Table 5). The 6 most numerous genera identified in descending order were Mucor (1,193), Aspergillus (685), Scopulariopsis (322), Fusarium (81), Penicillium (61), and Trichophyton (60). The overall concentration $( \pm$ SEM) of mesophilic fungi from lagoon wastewater grown on LOA was $1.3 \mathrm{E}+04( \pm 5.51 \mathrm{E}+03) \mathrm{cfu} / \mathrm{mL}$, and there were significantly $(P<0.05)$ more in the summer $(2.39 \mathrm{E}+04$ $\mathrm{cfu} / \mathrm{mL})$ than in the winter $(2.19 \mathrm{E}+03 \mathrm{cfu} / \mathrm{mL})$. There was a significant $(P<0.04)$ interaction between dairy lagoon location and season. 
Table 3. Comparison of biolog bacterial identification of colonies grown on MacConkey-sorbitol agar from 2 dairy lagoons in summer and winter $^{1}$

\begin{tabular}{|c|c|c|c|c|c|}
\hline Dairy & No. of isolates & Season & Colony color & Bacterial identification & Probability (\%) \\
\hline DL 4 & 1 & Winter & Colorless & Escherichia coli & 99 \\
\hline DL 4 & 12 & Winter & Pink & Escherichia coli & $97-99$ \\
\hline DL 4 & 2 & Summer & Pink & Citrobacter freundii & 99 \\
\hline DL 4 & 5 & Summer & Pink & Escherichia coli & $97-99$ \\
\hline DL 4 & 1 & Summer & Colorless & Providencia rettgeri & 99 \\
\hline DL 6 & 1 & Winter & Pink & Citrobacter sedlakii & 99 \\
\hline DL 6 & 8 & Winter & Pink & Escherichia coli & $94-99$ \\
\hline DL 6 & 2 & Winter & Colorless & Providencia rettgeri & 99 \\
\hline DL 6 & 1 & Winter & Colorless & Providencia stuartii & 99 \\
\hline DL 6 & 1 & Summer & Pink & Enterobacter cloacae & 80 \\
\hline DL 6 & 6 & Summer & Colorless & Morganella morganii & 99 \\
\hline DL 6 & 1 & Summer & Colorless & Pseudomonas spp. & NA \\
\hline DL 6 & 2 & Summer & Pink & Raoultella terrigena & 80,87 \\
\hline DL 6 & 1 & Summer & Pink & Salmonella choleraesuis & 99 \\
\hline
\end{tabular}

${ }^{1}$ DL 4 and DL 6 = dairy lagoon 4 and 6 . NA indicates that identification was to the genus only. Salmonella identified to 6 groups only: group 1 (Salmonella choleraesuis, Salmonella gallinarum, Salmonella paratyphi A, Salmonella typhi, Salmonella pullorum, and Salmonella typhimurium); group 3A (Salmonella arizonae); group 3B (Salmonella diarizonae); group 4 (Salmonella houtenae); group 5 (Salmonella bongori); and group 6 (Salmonella indica).

A total of 3,095 thermophilic fungal colonies were identified from the 4 dairy lagoons in winter and summer (Table 6). Five thermophilic fungal colonies were considered M. sterile because they possessed no identifying features. The most numerous lagoon waterborne thermophilic colonies identified were Penicillium $d u$ ponti (2,335), Montospora lanuginose (341), Montospora daleae (74), and Mucor pusillus (290). Chrysosporium zonatum is not listed as a known thermophilic fungus (Crisan, 1959), but it was isolated on 3 occasions from the lagoon wastewater. Chrysosporium zonatum grew well at $50^{\circ} \mathrm{C}$ and it passaged 3 times without growth inhibition. It was also isolated as a thermophilic agent from the ambient air of dairies (Purdy, unpublished data). The overall concentration ( \pm SEM) of thermophilic fungi from the wastewater was $7.71 \mathrm{E}+02$ ( \pm $8.91 \mathrm{E}+01) \mathrm{cfu} / \mathrm{mL}$, and there were significantly $(P<$ $0.05)$ more in the winter $(1.09 \mathrm{E}+03 \mathrm{cfu} / \mathrm{mL})$ than in the summer $(4.54 \mathrm{E}+02 \mathrm{cfu} / \mathrm{mL})$. There was a significant $(P<0.0001)$ interaction between dairy lagoon location and season and between dairy lagoon location and lagoon sample location. Thermophilic fungal colonies were not isolated from the 2 control lakes.

Lagoon yeast colonies isolated on LOA plates were colored white, cream, red or pink, blue, and brown.
There was no apparent association between color of yeast colony and genus type. A total of 5,678 yeast colonies were counted among the mesophilic fungal colonies on LOA plates. Twelve yeast colonies from DL 4 and 8 from DL 6 were identified by the Biolog auto-

Table 4. Salmonella enterica isolates recovered from 4 dairy lagoons and 2 control lakes ${ }^{1}$ (summer and winter), identified ${ }^{2}$ by serotype, and placed in descending order

\begin{tabular}{lc}
\hline Salmonella serotype & No. of isolates recovered \\
\hline Salmonella enterica Typhimurium & 56 \\
Salmonella enterica Montevideo & 48 \\
Salmonella enterica Kentucky & 30 \\
Salmonella enterica Newport & 28 \\
Salmonella enterica Cerro & 11 \\
Salmonella enterica Give & 8 \\
Salmonella enterica Dublin & 7 \\
Salmonella enterica Agona & 5 \\
Salmonella enterica Mbandaka & 3 \\
Salmonella enterica 5 other serovars) & 1 each \\
\hline
\end{tabular}

${ }^{1}$ No Salmonella spp. were recovered from the 2 control lakes.

${ }^{2}$ Identified by National Veterinary Services Laboratory (Ames, IA).

${ }^{3}$ Two varieties: Typhimurium and Typhimurium Copenhagen.

${ }^{4}$ Three varieties: 1 Give, 4 Give $(15+)$, and 3 Give $(15+),(34+)$.

${ }^{5}$ Five serovars: Anatum, Bredeney, Minnesota, Panama, and Worthington. 
Table 5. Mesophilic fungi from 4 dairy lagoons (DL 3, DL 4, DL 5, and DL 6) and 2 control lakes (CL 1 and CL 2) cultured on Littman oxgall agar at $28^{\circ} \mathrm{C}$ for $10 \mathrm{~d}^{1}$

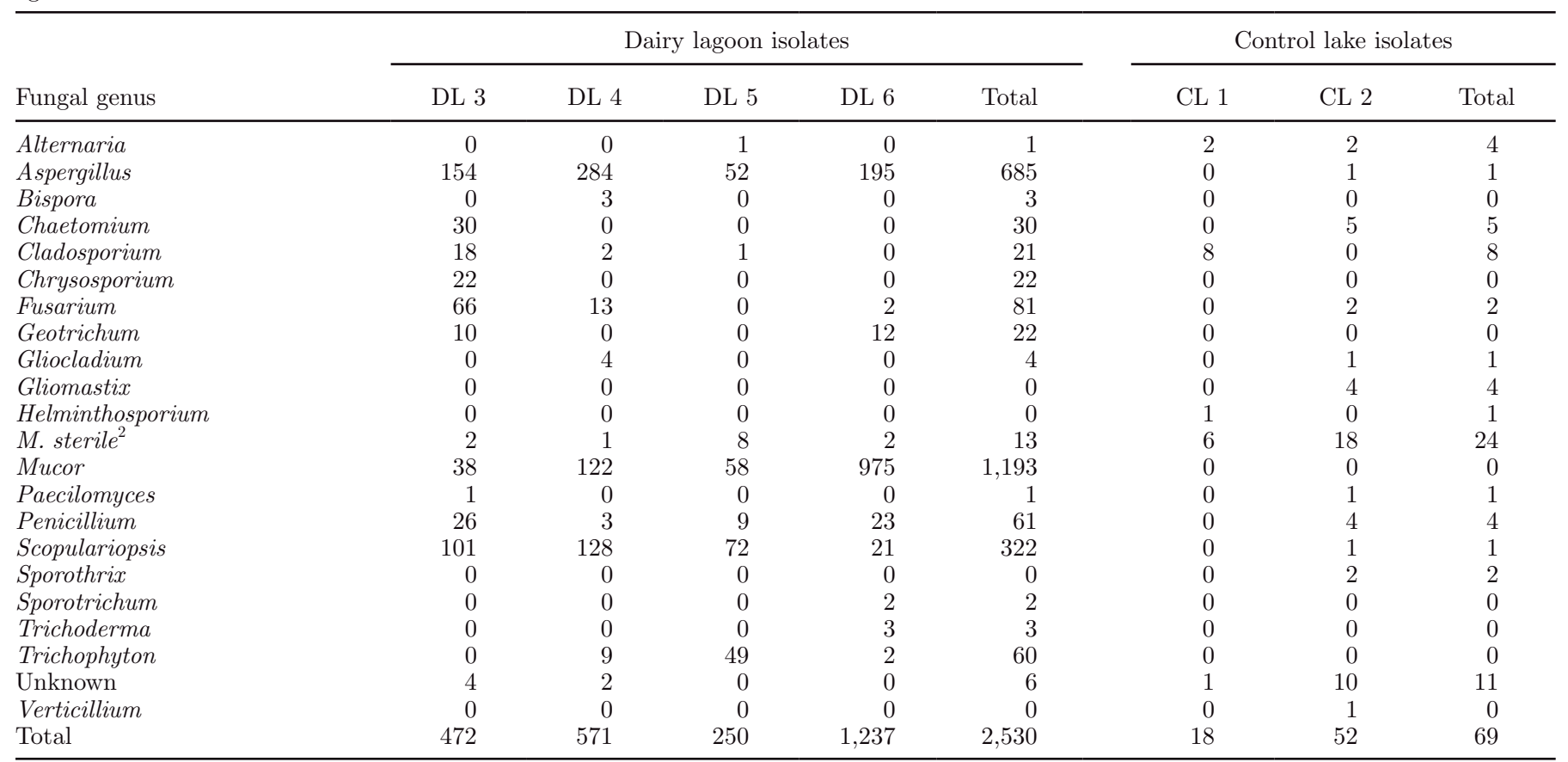

${ }^{1}$ Each culture was identified and the numbers of summer and winter isolates were combined for each dairy lagoon and each control lake.

${ }^{2}$ M. sterile $=$ cultures had no identifying spores.

mated system. The DL 4 isolates were Galactomyces geotrichum (3), Candida sorboxylosa (2), Rhodotorula glutinis (2), Candida ergastensis (1), Candida glabrata (1), Cryptococcus albidus (1), Cryptococcus curvatus A (1), and Issatchenkia orientalis (1). The DL 6 isolates were Candida sorboxylosa (4), Issatchenkia scutulata var. exigua (3), and Pichia onychis (1). The overall total concentration $( \pm \mathrm{SEM})$ of yeast colonies grown on LOA was $1.12 \mathrm{E}+04( \pm 4.84 \mathrm{E}+03) \mathrm{cfu} / \mathrm{mL}$, and no significant difference occurred between summer and winter. There was a significant $(P<0.03)$ interaction between dairy lagoon and season.
In addition, yeast isolates were identified from various locations of dairy 4 and dairy 6 . The following genera and species were identified: milk barn effluent: Candida pararugosa (1), Galactomyces gentrichum (1), Issatchenkia scutulata var. exigua (1), Trichosporon beigelii B (1), and Zygoascus hellenicus (1); ditch effluent: Bulleromyces albus (1), Candida sorboxylosa (2), Cr. albidus (9), Cryptococcus laurentii (1), Filobasidiella neoformans neoformans B (1), Galactomyces geotrichum (3), Pichia onychis (1), Pichia mexicana (1), Phaffia rhodozyma (1), Saccharomycodes ludwigii (1), and Trichosporon inkin (1); settling basin: Candida glabrata

Table 6. Total thermophilic fungi from 4 dairy lagoons (DL 3, DL 4, DL 5, and DL 6) cultured on malt extract agar at $50^{\circ} \mathrm{C}$ for 4 to $10 \mathrm{~d}^{1}$

\begin{tabular}{|c|c|c|c|c|c|}
\hline Fungal genus and species & DL 3 & DL 4 & DL 5 & DL 6 & Total isolates \\
\hline Aspergillus fumigatus & 0 & 0 & 24 & 0 & 24 \\
\hline Chaetomium thermophile & 7 & 0 & 3 & 2 & 12 \\
\hline Chrysosporium zonatum & 0 & 3 & 0 & 0 & 3 \\
\hline Malbrachea pulchella & 1 & 8 & 5 & 2 & 16 \\
\hline Monotospora daleae & 42 & 15 & 0 & 17 & 74 \\
\hline Monotospora lanuginosa & 168 & 163 & 7 & 3 & 341 \\
\hline Mucor pusillus & 164 & 63 & 1 & 62 & 290 \\
\hline Penicillium duponti & 241 & 364 & 13 & 1,717 & 2,335 \\
\hline M. sterile ${ }^{2}$ & 5 & 0 & 0 & 0 & 5 \\
\hline Total & 628 & 616 & 53 & 1,803 & 3,100 \\
\hline
\end{tabular}

${ }^{1}$ Each isolate was identified, and winter and summer numbers were combined. No thermophilic fungi were isolated from the 2 control lakes.

${ }^{2}$ M. sterile $=$ cultures without spores. 
(1), Candida intermedia (1), Candida sorboxylosa (3), Candida tropicalis B (3), Cr. albidus var. aerius (1), Dipodascus ovetensis (1), Issatchenkia orientalis (1), and Rhodotorula aurantiaca A (1); and feed alley pad flush: Cr. albidus (1), Cryptococcus luteolus (1), Issatchenkia scutulata var. exigua (2), Pichia jadinii (1), Rhodotorula acheniorum (1), and Trichosporon beigelii B (1).

Control lake yeast colonies were colored white, pink, and orange, and very few colonies were isolated in the winter. Control lake 1 had only 1 colony and CL 2 had 2 colonies, and in the summer CL 1 had 9 colonies compared with CL 2, which had 312 colonies. Yeast colonies from CL 1 were identified as Cr. albidus (1), Cryptococcus marinus (1), and R. glutinis (2). Summer yeast isolates from CL 2 were identified as $B$. albus (3), Candida edex (8), Candida parapsilosis B (1), Cr. marinus (8), Debaryomyces castellii (1), Debaryomyces hansenii (1), R. acheniorum (1), R. glutinis (4), Rhodotorula graminis (1), and Rhodotorula minuta (1).

\section{DISCUSSION}

Purdy et al. (2001b) have shown that dairy lagoons, like feedyard playas, have high concentrations of endotoxins because of the high concentrations of gramnegative bacteria found in manure. It has been shown by Purdy et al. $(2002 \mathrm{a}, 2007)$ that, where the lipid A portion contains the toxins, endotoxins are bioreactive when inhaled by animals or humans and induce a rapid increase in body temperature within 4 to $6 \mathrm{~h}$ and an increase in total white blood cell counts within $12 \mathrm{~h}$. Very little is known about how endotoxins are degraded in the environment or how long it takes. However, Purdy et al. (2002b) have shown that endotoxins are resistant to heat.

No Environmental Protection Agency standards are set for maximum concentrations of endotoxin in air or water in the United States. A proposed occupational exposure limit for endotoxin is $30 \mathrm{ng} / \mathrm{m}^{3}$ of air. As developed by Palchak et al. (1988), the proposed occupational exposure limit was for an 8-h time-weighted average. The Dutch have recommended health-based endotoxin exposure limits of $5 \mathrm{ng} / \mathrm{m}^{3}$ of air and temporary legal limits of $20 \mathrm{ng} / \mathrm{m}^{3}$ of air (Spaan et al., 2006). Several occupations are known for their increased levels of endotoxin: occupations in which workers spend time in corn storage facilities ( $85 \%$ of samples $<50 \mathrm{ng} / \mathrm{m}^{3}$; Todd and Buchan, 2002), municipal sewage treatment plants (0.104-320 ng $/ \mathrm{m}^{3}$; Laitinen et al., 1994; Prazmo et al., 2003), or composting facilities $\left(640 \mathrm{ng} / \mathrm{m}^{3}\right.$; Epstein et al., 2001), and agriculture practices in general that place organic dust in the air (Viet et al., 2001). For example, Gora et al. (2004) have shown that picking and sorting hops (Humulus lupulus) resulted in dust samples that contained endotoxin (range: 312.5-6,250 $\mu \mathrm{g} / \mathrm{g}$ ). Viet et al. (2001) demonstrated that inhalation of endotoxin doses of 4 to $15 \mathrm{ng} / \mathrm{m}^{3}$ for $8 \mathrm{~h}$ has been associated with acute and chronic airway inflammation and lung function decrements.

Purdy et al. (2001b) showed that the overall mean endotoxin concentrations of 4 large dairies (summer: $3,220 \mathrm{ng} / \mathrm{mL}$; winter: $9,679 \mathrm{ng} / \mathrm{mL}$ ) was comparable to those determined in 7 large feedyard retention ponds (summer: 8,640 ng/mL; winter, 8,001 ng/mL). In the same study, bottom sediment of feedyard playas was significantly higher $(17,700 \mathrm{ng} / \mathrm{g})$ in endotoxin compared with the water values. Therefore, dairy lagoon wastewater should be used in a manner that would not potentially endanger the health of humans or cattle. The data indicate that this water should not be used for dust abatement in the loafing pens or on the roads because when the abated dust dries and becomes airborne, it will be further enriched with endotoxins that may be inhaled by both humans and cattle. In addition, enteric pathogens are spread to a larger environmental area by vehicle tires and human walking.

There is historical evidence that nitrate contamination of ground water is increasing in Kansas and in most areas of the High Plains Aquifer in western Texas, as shown by Litke (2000). Also, a Kansas Geological Survey reported that nitrates had increased between the 1970s and the 1990s in three-fourths of the wells that they sampled in central and western Kansas (Townsend and Young, 1999). The $\mathrm{NH}_{4}-\mathrm{N}(397 \mathrm{mg} / \mathrm{L})$ and TKN $(607 \mathrm{mg} / \mathrm{L})$ contents of 2 western Kansas dairy lagoons (DeSutter et al., 2000) and 7 Kansas dairy lagoons had a mean $\mathrm{NH}_{4}-\mathrm{N}$ content of $398 \mathrm{mg} / \mathrm{L}$ and TKN content of $816 \mathrm{mg} / \mathrm{L}$ (Strahm et al., 2000). These Kansas values were considerably larger than those of the 4 dairies from the SHP from which samples were collected. Here, the $\mathrm{NH}_{4}-\mathrm{N}$ content was 2.2 times lower $(181 \mathrm{mg} / \mathrm{L})$ and TKN was 3.3 times lower $(249 \mathrm{mg} / \mathrm{L})$. The SHP dairy lagoon values for $\mathrm{NH}_{4}-\mathrm{N}$ (winter: $88 \mathrm{mg} / \mathrm{L}$; summer: 78 $\mathrm{mg} / \mathrm{L}$ ) and TKN (winter: $94 \mathrm{mg} / \mathrm{L}$; summer: $203 \mathrm{mg} / \mathrm{L}$ ) were higher than those found in 7 feedyard retention ponds, as shown by Purdy et al. (2001b). Most values observed in the dairy wastewater were lower than those found in the 7 feedyard playas, except for electrical conductivity (5.7 mSiemens/cm), turbidity $(13.1 \%$ at $650 \mathrm{~nm}), \mathrm{pH}(7.93), \mathrm{NO}_{3}-\mathrm{N}(0.714 \mathrm{mg} / \mathrm{L}$ in winter $)$, $\mathrm{Cl}^{-}(933 \mathrm{mg} / \mathrm{L})$, and $\mathrm{Na}^{+}(205 \mathrm{mg} / \mathrm{L})$. The $\mathrm{NaCl}$ salt was less concentrated in the dairy lagoons compared with in the feedyard playas.

Sulfate concentrations were significantly $(P<0.05)$ higher (8.5 times) in DL $5(84.5 \mathrm{mg} / \mathrm{L})$ compared with the other 3 lagoons (range: $9.9-10.9 \mathrm{mg} / \mathrm{L}$ ) and the 
control lakes (range: 3.0-5.78). Dairy 5 has a history of foot-rot problems and their treatment was $\mathrm{Cu}-\mathrm{SO}_{4}{ }^{2-}$ footbaths. The effluent from these footbaths ran into the lagoon, and the maximum $\mathrm{SO}_{4}{ }^{2-}$ concentration $(145 \mathrm{mg} / \mathrm{L})$ sampled was located on the east side of the lagoon near the inlet pipe.

The Biolog automated system identified several genera and species from the $E$. coli enrichment broth used to select for Enterobacteriaceae from the dairy lagoons. The absence of E. coli O157:H7 from the identified list was a surprise because of the large amount of these organisms expelled by the cattle during defecation. However, this is in agreement with a report by Ravva et al. (2006) that concluded that E. coli O157:H7 failed to establish and proliferate in dairy lagoon wastewater equipped with or without circulating aerators. Escherichia coli O157:H7 was identified from 3 locations on dairy 4 in the winter.

It was unexpected that no $E$. coli were identified from DL 6 in the summer. The Salmonella enrichment broth inoculated with dairy lagoon water and passed to selective Salmonella media (MAC, BGA, and XLD) and followed by appropriate biochemistry test was successful. The presumptive success rate for Salmonella spp. isolates overall was 70\% (MAC: 63\%; BGA: 61\%; and XLD: $85 \%$ ). Using all 3 of the Salmonella-selective media will hopefully allow for a better selection of serovars.

Bacterial, human, and animal pathogens isolated were Salmonella spp. and Providencia alcalifaciens. A study by Wenz et al. (2001) on bovine coliform mastitis included 4 of the genera identified, which can account for 14 to $17 \%$ of mastitis in general (Sargeant et al., 1998). Systemic bacteremia is frequently associated with acute coliform mastitis. Of course, all Enterobacteriaceae isolates not considered specific pathogens can be considered opportunistic pathogens.

Fungal growth in dairy lagoons has been underrepresented when compared with the number of publications on bacterial growth in wastewater. Perhaps this is because nitrification (Schmidt and Belser, 1994) and denitrification (Tiedje, 1994) have long been considered a bacterial-based product. Guest and Smith (2002) recently discussed newly recognized roles that fungi play in the treatment of wastewater. In this study, filamentous fungi were recognized to have potential advantages over bacteria in terms of rate reaction, stoichiometry, and resistance to inhibition. They also demonstrated that fungal effectiveness in nutrient removal and solids separation could be investigated by using new membrane bioreactor technology.

Fakhru'l-Razi et al. (2002) carried out a study to identify specific filamentous fungi of domestic wastewa- ter sludge that would enhance biodegradability, settleability, and dewaterability of the treated sludge. In this study, they isolated 70 strains of filamentous fungi from wastewater, sewage sludge, and leachate. They observed strains belonging to the following genera: Penicillium, Aspergillus, Trichoderma, Spicaria, and Hyaloflorae. In a different study, Alam and Fakhru'l-Razi (2003) determined that sludge treated with Aspergillus niger and Penicillium corylophilum enhanced sludge particle formation (larger particles) for a better separation process than that observed in untreated sludge. Wastewater is naturally colored (brown) by melanoidin, and Miyata et al. (2000) determined that a fungus (Coriolus hirsutus) has the ability to decolorize (catabolize) melanoidin. Price et al. (2001) showed that another fungus, Aspergillus niger, has the ability to absorb $\mathrm{Cu}$ and $\mathrm{Zn}$ from wastewater. Boer et al. (2005) stated that fungi have always been part of decomposing the manure solids in wastewater because they are superior microbial agents at breaking down cellulose and lignin contained in plants.

In this study, the most numerous mesophilic filamentous fungi identified from the lagoon wastewater were, in decreasing order, Mucor, Aspergillus, and Scopulariopsis, and the thermophilic fungi identified were Penicillium duponti, Mucor pusillus, Monotospora lanuginose, and M. daleae. Publications concerning the identification of thermophilic fungi from wastewater were not found in the literature. The mesophilic fungi concentration and the yeast concentration were about equal, similar to a published report (Standard Methods for the Examination of Water and Wastewater, 1995). Purdy et al. (2004b) demonstrated that all of the filamentous fungi identified in the dairy lagoon wastewater were from soil and all have been identified from ambient air.

There were 7 genera and 10 species of yeast isolated and identified from 2 of the dairy lagoons. Of those identified, Candida glabrata is of interest because it is considered an opportunistic agent, is one of the most common yeast species found on body surfaces, and has been implicated in both superficial and systemic human infections. Two hundred-fifty cases of human vulvovaginal candidosis were investigated by Ilkit et al. (2007), and $32 \%$ of the yeast identified was Ca. glabrata. Two of the 7 genera identified (Rhodotorula and Candida) plus Trichosporon were isolated from mastitic dairy herds in Poland by Krukowski et al. (2001). Another isolate, Cr. albidus, was identified in a fatal systemic infection by Kordossis et al. (1998). Cryptococcus albidus with Cr. laurentii infections have been increasing over the past 40 yr (Khawcharoenporn et al., 2007). Galactomyces geotrichum and other genera have been 
identified by Cheatwood et al. (2003) as a stomatitis agent in free-ranging pigmy rattlesnakes (Sistrurus miliarius barbouri).

In conclusion, new information was revealed through this dairy lagoon research. Several important soil mesophilic fungi, including yeast and thermophilic fungi, were identified from dairy wastewater located on the SHP. These microbes along with bacteria play an important part in decomposing manure biosolids in dairy lagoons. The lagoon wastewater contains a high concentration of endotoxins and a variety of pathogens; therefore, our hypothesis was proven. Twenty-eight Salmonella spp. isolates were identified in the wastewater from irrigation center pivots.

The data generated in this study should be an important reminder to dairy managers to use their wastewater in a responsible way and not expose their employees or animals to unnecessary aerosols. They should not increase the size of the environmental area exposed to pathogen contamination or increase the concentration of endotoxin dust-laden pollution, and rarely use forage (green chop) within the few days following irrigation with lagoon water. The manager needs to realize that it takes time for water-transported pathogens to die on the forage crop. Pathogen death occurs through the lapse of time, dehydration, and UV light irradiation, and the curing process should not be rushed (Purdy et al., 2001a). These data show that the practice of using lagoon water to flush alley pads several times a day is not necessarily a good practice because large areas of the dairy are then exposed to microbial pathogens found in the lagoon.

\section{REFERENCES}

Alam, M. Z., and A. Fakhru'l-Razi. 2003. Enhanced settleability and dewaterability of fungal treated domestic wastewater sludge by liquid state bioconversion process. Water Res. 37:1118-1124.

Boer, W., L. B. Folman, R. C. Summerbell, and L. Boddy. 2005. Living in a fungal world: Impact of fungi on soil bacterial niche development. FEMS Microbiol. Rev. 29:795-811.

Burchfield, G., and S. Linderoth. 1999. Region sees growth as dairy industry shift continues. Dairy Producer, December. www. moomilk.com

Centner, T. J. 2001. Evolving policies to regulate pollution from animal feeding operations. Environ. Manage. 28:599-609.

Cheatwood, J. L., E. R. Jacobson, P. G. May, T. M. Farrel, B. L. Homer, D. A. Samuelsom, and J. W. Kimbrough. 2003. An outbreak of fungal dermatitis and stomatitis in a free-ranging population of pigmy rattlesnakes (Sistrurus milliarius barbouri) in Florida. J. Wildl. Dis. 39:329-337.

Cole, D., L. Todd, and S. Wing. 2000. Concentrated swine feeding operations and public health: A review of occupational and community health effects. Environ. Health Perspect. 108:685699 .

Cook, J. M. 1989. Methods of Chemical Analysis of Ground Water. Scientific Publishers, India.

Crisan, E. V. 1959. The isolation and identification of thermophilic fungi. MS Thesis. Department of Microbiology, Purdue University, West Lafayette, IN.
DeSutter, T. M., J. M. Ham, and T. P. Trooien. 2000. Survey of waste chemistry of anaerobic lagoons at swine production facilities and cattle feedlots. Internal document. Kansas State University Research \& Extension, Manhattan.

Difco. 1984. Difco Manual. 10th ed. Difco Laboratories, Detroit, MI.

Environmental Protection Agency. 1997. Test methods for evaluating solid waste. http://www.epa.gov/waste/hazard/testmethods/ index.htm

Epstein, E., N. Wu, C. Youngberg, and G. Croteau. 2001. Dust and bioaerosols at a composting facility. Compost Sci. Util. 9:250255.

Fakhru'l-Razi, A., M. Z. Alam, A. Idris, A. S. Abdul, and A. H. Molla. 2002. Filamentous fungi in Indah Water Konsortium (IWK) sewage treatment plant for biological treatment of domestic wastewater sludge. J. Environ. Sci. Health A Tox. Hazard Subst. Environ. Eng. 37:309-320.

Gora, A., C. Skorska, J. Sitkowska, Z. Prazmo, E. Krysinska-Traczyr, B. Urbanowicz, and J. Dutkiewicz. 2004. Exposure of hop growers to bioaerosols. Ann. Agric. Environ. Med. 11:129-138.

Guest, R. K., and D. W. Smith. 2002. A potential new role for fungi in a wastewater MBR biological nitrogen reduction system. J. Environ. Eng. Sci. 1:433-437.

Hepburn, N. F., M. MacRae, M. Johnston, J. Mooney, and I. D. Ogden. 2002. Optimizing enrichment conditions for the isolation of Escherichia coli O157 in soils by immunomagnetic separation. Lett. Appl. Microbiol. 34:365-369.

Ilkit, M., S. Hilmioglu, M. Tasbakan, and S. Aydemir. 2007. Evaluation of Albicans ID2 and Biggy agar for the isolation and direct identification of vaginal yeast isolates. J. Med. Microbiol. $56: 762-765$.

Khawcharoenporn, T., A. Apisarnthanarak, and L. M. Mundy. 2007. Non-neoformans cryptococcal infections: A systematic review. Infection 35:51-58.

Kordossis, T., A. Avlami, A. Velegraki, I. Stefanou, G. Georgakopoulos, C. Papalambrou, and N. J. Legakis. 1998. First report of Cryptococcus laurentii meningitis and a fatal case of Cryptococcus albidus cryptococcaemia in AIDS patients. Med. Mycol. 36:335339.

Krukowski, H., M. Tietze, T. Majewski, and P. Rozanski. 2001. Survey of yeast mastitis in dairy herds of small-type farms in the Lubilin region, Poland. Mycopathologia 150:5-7.

Laitinen, S., J. Kangas, M. Kotimaa, J. Liesivuori, P. J. Martikainen, A. Nevalainen, R. Sarantila, and K. Husman. 1994. Workers' exposure to airborne bacteria and endotoxins at industrial wastewater treatment plants. Am. Ind. Hyg. Assoc. J. 55:1055-1060.

Larone, D. H. 1995. Medically Important Fungi: A Guide to Identification. 3rd ed. ASM Press, Washington, DC.

Litke, D. W. 2000. Historical water quality data for the High Plains Regional Groundwater Study Area in Colorado, Kansas, Nebraska, New Mexico, Oklahoma, South Dakota, Texas, and Wyoming, 1930-1998. US Geological Survey WRI report 00-4254. 2000. US Geological Survey, Reston, VA.

Miyata, N., T. Mori, K. Iwahori, and M. Fujita. 2000. Microbial decolorization of melanoidin-containing wastewaters: Combined use of activated sludge and the fungus Coriolus hirsutus. J. Biosci. Bioeng. 89:145-150.

Palchak, R. B., R. Cohen, M. Ainslie, and C. L. Hoerner. 1988. Airborne endotoxin associated with industrial-scale production of protein products in gram-negative bacteria. Am. Ind. Hyg. Assoc. J. 49:420-421.

Prazmo, Z., E. Krysinska-Traczyk, C. Skorska, J. G. Sitkowska, and J. Dutkiewicz. 2003. Exposure to bioaerosols in a municipal sewage treatment plant. Ann. Agric. Environ. Med. 10:242-248.

Price, M. S., J. J. Classen, and G. A. Payne. 2001. Aspergillus niger absorbs copper and zinc from swine wastewater. Bioresour. Technol. 77:41-49.

Purdy, C. W., D. C. Straus, N. Chirase, D. B. Parker, J. R. Ayers, and M. D. Hoover. 2002a. Effects of aerosolized feedyard dust that contains natural endotoxins on adult sheep. Am. J. Vet. Res. 63:28-35. 
Purdy, C. W., D. C. Straus, and R. N. Clark. 2004a. Diversity of Salmonella serovars in feedyard and nonfeedyard playas of the Southern High Plains in the summer and winter. Am. J. Vet. Res. 65:1-5.

Purdy, C. W., D. C. Straus, J. A. Harp, and R. Mock. 2001a. Microbial pathogen survival study in a high plains feedyard playa. Tex. J. Sci. 53:247-266.

Purdy, C. W., D. C. Straus, and M. D. Hoover. 2007. Fever and leukocytosis responses in goats to inhaled endotoxin are dosedependent. Small Ruminant Res. 70:140-144.

Purdy, C. W., D. C. Straus, D. B. Parker, J. R. Ayers, and M. D. Hoover. 2002b. Treatment of feedyard dust containing endotoxin and its effect on weanling goats. Small Ruminant Res. 46:123132.

Purdy, C. W., D. C. Straus, D. B. Parker, B. P. Williams, and R. N. Clark. 2001b. Water quality in cattle feedyard playas in winter and summer. Am. J. Vet. Res. 62:1402-1407.

Purdy, C. W., D. C. Straus, D. B. Parker, S. C. Wilson, and R. N. Clark. 2004b. Comparison of the type and number of microorganisms and concentration of endotoxin in the air of feedyards in the Southern High Plains. Am. J. Vet. Res. 65:45-52.

Ravva, S. V., C. Z. Sarreal, B. Duffy, and L. H. Stanker. 2006. Survival of Escherichia coli O157:H7 in wastewater from dairy lagoons. Appl. Microbiol. 101:891-902.

Sargeant, J. M., H. M. Scott, K. E. Lesile, M. J. Ireland, and A. Bashiri. 1998. Clinical mastitis in dairy cattle in Ontario: Frequency of occurrence and bacteriological isolates. Can. Vet. J. 39:33-38.

Schmidt, E. L., and L. W. Belser. 1994. Autotrophic nitrifying bacteria. Pages 159-177 in Methods of Soil Analysis. Part 2. Microbiological and Biochemical Properties. J. M. Bigham, ed. Soil Science Society of America, Madison, WI.

Spaan, S., I. M. Wouters, I. Oosting, G. Doekes, and D. Heederik. 2006. Exposure to inhalable dust and endotoxins in agricultural industries. J. Environ. Monit. 8:63-72.
Standard Methods for the Examination of Water and Wastewater. 1995. www.standardmethods.org

Strahm, T. D., J. P. Harner III, D. V. Key, and J. P. Murphy. 2000. Lagoon nutrients from scraped and flushed dairy waste systems. Am. Soc. Agric. Engr. paper no. 002207. Presented at the 93rd Annual Meeting of ASAE, Milwaukee, WI.

Thorne, P. S. 2007. Environmental health impacts of concentrated animal feeding operations: Anticipated hazards-Searching for solutions. Environ. Health Perspect. 115:296-297.

Tiedje, J. M. 1994. Denitrifiers. Pages 245-267 in Methods of Soil Analysis. Part 2. Microbiological and Biochemical Properties. J. M. Bigham, ed. Soil Science Society of America, Madison, WI.

Todd, B. E., and R. M. Buchan. 2002. Total dust, respirable dust, and microflora toxin concentrations in Colorado corn storage facilities. Appl. Occup. Environ. Hyg. 17:411-415.

Townsend, M. A., and D. P. Young. 1999. Nitrates in Kansas groundwater. Public information circular no. 14. Kansas Geological Survey, Lawrence, KS.

Uvacek, E. 1984. The economics of the cattle industry. Pages 3-6 in Bovine Respiratory Disease: A Symposium. R. W. Loan, ed. Texas A\&M University, College Station.

Viet, S. M., R. Buchan, and L. Stallones. 2001. Acute respiratory effects and endotoxin exposure during wheat harvest in Northeastern Colorado. Appl. Occup. Environ. Hyg. 16:685-697.

Wenz, J. R., G. M. Barrington, F. B. Garry, K. D. McSweeney, R. P. Dinsmore, G. Goodell, and R. J. Callan. 2001. Bacteremia associated with naturally occurring acute coliform mastitis in dairy cows. J. Am. Vet. Med. Assoc. 219:976-981.

Williams, P. B., and J. F. Halsey. 1997. Endotoxin as a factor in adverse reactions to latex gloves. Ann. Allergy Asthma Immunol. 79:303-310. 